Consuming Life in Post-Bubble Japan 


\section{Consumption and Sustainability in Asia}

Asia is the primary site of production of a myriad of commodities that circulate the globe. From cars and computer chips to brand clothing, material objects manufactured across Asia have become indispensable to people's lives in most cultural contexts. This mega production generates huge amounts of waste and pollution that threaten the health and lifestyle of many Asians. Yet, Asia is not only a site of production, but also one of the most rapidly growing consumer markets.

This series focuses on consumption - the engine propelling Asia onto the world economic stage - and its implications, from practices and ideologies to environmental sustainability, both globally and on the region itself. The series explores the interplay between the state, market economy, technologies, and everyday life, all of which have become defining facets of contemporary Asian culture. Shifts in consumption that have taken place across Asia since the 1950s have had a deep impact on new and emerging informal economies of material care, revealing previously invisible sites of innovation, resistance and co-option. The series will bring together studies by historians, anthropologists, geographers, and political scientists that systematically document and conceptualize Asia's engagement with consumption and sustainability in the global environment.

Series Editors

Nir Avieli, Ben Gurion University of the Negev, Beer-Sheva

Katarzyna Cwiertka, Leiden University

Assa Doron, Australian National University 


\title{
Consuming Life in Post-Bubble Japan
}

A Transdisciplinary Perspective

\author{
Edited by \\ KatarzynaJ. Cwiertka and Ewa Machotka
}


Cover illustration: Morimura Yasumasa, Elder Sister, 1991. Chromogenic print on canvas, $783 / 4 \times 471 / 4$ inches $(200 \times 120 \mathrm{~cm})$

(c) Morimura Yasumasa. Courtesy of the artist and Luhring Augustine, New York

Cover design: Coördesign, Leiden

Typesetting: Crius Group, Hulshout

Amsterdam University Press English-language titles are distributed in the US and Canada by the University of Chicago Press.

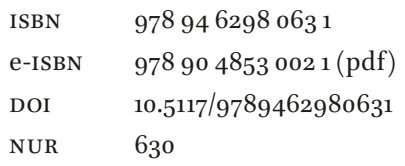

Creative Commons License CC BY NC ND (http://creativecommons.org/licenses/by-nc-nd/3.o)

@ All authors / Amsterdam University Press B.V., Amsterdam 2018

Some rights reserved. Without limiting the rights under copyright reserved above, any part of this book may be reproduced, stored in or introduced into a retrieval system, or transmitted, in any form or by any means (electronic, mechanical, photocopying, recording or otherwise). 